\title{
The Role of Parents in Strengthening the Character of Responsibility in the Family in the Covid-19 Pandemic Period
}

\author{
Mery Yanti*, Marzuki \\ Department of Pancasila and Civic Education, Faculty of Social Science, Yogyakarta State University, Yogyakarta \\ Indonesia \\ *Corresponding author. Email: mery0034pasca.2019@student.uny.ac.id
}

\begin{abstract}
The implementation of learning for the 2020 academic year during the Covid-19 epidemic was carried out boldly. Student study and do activities at home. Parents are required to have quality conditions following their upbringing patterns so that parents can provide adequate stimulation. For the child's potential to develop and possibly, with the parenting style and the stimulus provided is not appropriate, it has a negative potential. This study aims to see how parents' role in their responsibilities during the COVID-19 pandemic. The data technology used is structured interviews, data obtained through interviews as primary data, and literature study as secondary data. Based on the research, it can be ignored that parents' role in the responsibility of responsibility through, (1) always discipline, responsibility. (2) taught through habituation, appreciation, and advice. (3) set a good example. (4) during holidays, children are allowed to play with gadgets or friends. (5) provide and equip religious knowledge.
\end{abstract}

\section{Keywords: The Role of Parents, Strengthening Character, Responsibilities}

\section{INTRODUCTION}

Character education is a close problem and needs to be addressed by the Indonesian people. Therefore, character education must be pursued in totality because students can negatively influence technological developments. [1] adds that the shock of globalization has caused various kinds of crises that have damaged the nation's image and confidence. Character education aims to assess children's necessary foundations as preparation for life and adapt to their environment [2].

Pandemic during the COVID-19 era Character strengthening is urgently needed. Indonesia has implemented technology learning by using gadgets as its medium. Fathoni (2017) reveals that Gadgets are one of the most popular technologies today, not only for adults but also for children who use gadgets. Gadgets are defined as small electronic devices with various special functions [3].

He role of parents in accompanying children's success while studying at home is very central; WHO (2020) released various guidelines for parents in accompanying children during this pandemic, which includes tips on parenting to be more positive and constructive in accompanying children's attitudes and skills during this pandemic. . . activities at home. Parents play a role in guiding attitudes and skills, such as providing religious education to obey the rules and good habits [4].

Parents' role in strengthening the character of responsibility for children is vital because parents are the place where children will get their first education since birth. This is by [5] where the two parents' role, especially and including family, has an enormous influence, even greatly influencing the behavior of the child and his family's mental life and personality. Therefore, a child's good and bad character are determined by the system of guidance, training, and education provided by parents to their children.

During the COVID-19 pandemic, parents have a lot of time with their children so that children tend to develop through parental care. Parental involvement is very important in helping children from learning limitations, improving social relationships and teaching children about their awareness of their interest in learning. Parents in Telukmerbau Village RT002 / RW001 have different ways of treating children, and each method of care has advantages and disadvantages. Parents are required to have quality conditions that are in accordance with parenting styles so that parents can provide good stimulation. The goal is that the potential for children to develop as well as possible, the steps for 
parenting and the stimulus provided are not appropriate, so that it is negative.

Parents must realize that developing good character will determine their child's future, Modeling moral education and habits is one of the strategies for character building in children. Exemplary parents can provide examples of behavior to their children. Habits in the character education process are essential. Habit is a very effective way of character education for children.

Based on this description, a child's self-confidence is closely related to the parents' role in accompanying and guiding children while at home. The role of parents in this COVID-19 pandemic situation has an absolute position. Based on the description above, the researcher wants to see to what extent the role of parents in guiding children during learning at home is an effort to strengthen children's character in carrying out their responsibilities.

Since the Coronavirus spread in Indonesia in early March, it has caused the government to take firm action to prevent a wider spread immediately. Because in this case, the disease caused by the Coronavirus can spread very quickly and has claimed many lives in various countries, so the government has made various efforts to prevent an extensive spread, one of which is by implementing distance learning, both from the level of elementary to college level [6]. In its implementation, parents who will accompany children in the learning process by utilizing technology to address distance learning problems, according to Nadiem Makariem, the Indonesian Minister of Education and Culture, many show that a pandemic situation requires PJJ hurts children. This impact can be prolonged if no action is taken. The first impact is the threat of dropping out of school because many children are already working due to several factors. Starting from PJJ, that is not optimal to the absence of supporting facilities for PJJ. Also, there are some changing perceptions of parents regarding schools' role in the learning process because PJJ is not optimal. The second impact is the threat of decreasing learning achievement because there is a change in quality between those who have access to technology and is not getting more significant. The third impact is violence against children during PJJ. Children also have psychosocial risks due to constant stress at home and not being able to meet friends. However, on the other hand, according to Nadiem Makarim, child health and safety factors are also very important.

Therefore, parents pay more attention and guide children better, so that worrying things do not happen. Therefore, parents' role as teachers at home is needed in guiding during the distance learning process. According the role of parents during Distance Learning (PJJ) has the role of teachers at home, where parents can guide their children's distance in learning remotely from home, parents as facilitators, namely parents as means and pre means for carrying out distance learning, parents as motivators, namely parents can provide enthusiasm and support to their children in carrying out learning, so that children have the enthusiasm to learn and get exemplary achievements, and parents as influences or directors.

\section{METHOD}

qualitatively describes the state of the object under study. Qualitative descriptive research aims to provide descriptive information or describe a condition in precise detail [7]. The data technique used was structured interviews. Data obtained by interviewing as primary data and literature study as secondary data. This research was conducted in Telukmerbau Village RT002 / RW001 Kec. Kubu. Kb. Rokan Hilir. Riau Province. The research subject's determination was carried out in a purposive manner, which was adjusted to the research objectives [8]. The research subjects were determined based on the evaluation of parents regarding the information needed in the study. Therefore, subjects with the appropriate style are the child's parents with the initials (NL), (VE), (LI,) and $(\mathrm{AB})$. The research data technique is the first, based on data compiled from interview guidelines with respondents online via a google form. Second, data reduction consists of grouping the results of interviews from respondents, conducting credibility tests, and triangulating sources. Third, the data presentation consists of a various compilation of results of grouping interviews with sources and describing them. I do not know the conclusions drawn from reports about parents' role in family responsibilities in COVID-19.

\section{RESULT AND DISCUSSION}

\subsection{Result}

Telukmerbau Village RT002 / RW001 revealed that the Corona Virus, or called COVID-19 in 2020, made the year different from previous years. This is felt directly by the community, especially the units in the community, namely the family. The government sets policies regarding work at home (school from home) policies. This policy positively affects the learning system in schools. Learning from home requires a direct role from parents because parents have an essential role in supporting learning from home. During the COVID-19 pandemic, the role of parents and parenting styles used by parents in the care, care, and educational assistance of children is vital.

The implementation of distance learning certainly involves parents in the learning process, so parents are expected to order the character of responsibility for children during the COVID-19 pandemic. Measurement of strengthening children's character during the Covid-19 pandemic was carried out using a questionnaire created in the google form application as a research data instrument. Based on the results of filling out a questionnaire via a google form distributed by the author to several parents in Telukmerbau Village RT002 / RW001 with the initials (NL), (VE), (LI,) and (AB), it is stated that character education in the family can be 
interpreted as a way from parents to children, so that children starting from an early age, adolescents to adults can grow by achieving moral values to prepare for an independent life and become a person with noble character. The strengthening of parents' character education during the COVID-19 pandemic in children can be collected through the following. First, always teach discipline and responsibility with examples of homework that have been divided, starting from small things that can be practiced. Second, the procedures for habituation, control, appreciation, and advice. Third, to set a good role model for children, they must obey the rules that apply at home, one of which is to go home before sunset and study after evening. Third, entering a holiday will allow children to play with devices or play with friends. Fourth, equip children with religious sciences because religion governs fellow humans.

\subsection{Discussion}

Parents' role is significant in order children's character in the middle of learning at home because the role of parents must be strengthened to provide substantial assistance during the COVID-19 pandemic. Parents are a subsystem of the interaction between parents and children. They play a role in protecting, raising, and disciplining children talking about parents' role, regardless of the family. $n$ terms of its function, the family has duties and functions of service, emotional support, material, and fulfillment of a company. [9] stated that parental care for their children could affect the child's character and behavior. The family cannot be taken from the child's life, which is the first and first place to start his life. In the family, religious, moral, and social values can be done more effectively, do this in other institutions. As carried out by [10] the family plays a vital role in instilling religious and moral values according to age and family culture.

The government has issued Presidential Regulation Number 87 of 2017 concerning strengthening character education (PPK). The aim of this Presidential Decree is, of course, to form a cultured national personality through strengthening the character values extracted from the culture of the Indonesian nation itself. Strengthening Character Education (PPK) is an effort by the government under the education unit to oversee students' character through harmonization by heart, by thought, my body, including the three academic units, namely school, family, and community. Furthermore, it is followed up with Permendikbud Number 20 of 2018 concerning strengthening character education (PPK), recommendation on character education, namely by implementing character education based on the principles of Pancasila by instilling a religious attitude, honesty, tolerance, discipline, hard work, creative, independent, democratic, feeling curious, national spirit, love for the country, respect for achievement, communicative, love peace, reading, care for the environment, care socially, and be responsible. This attitude analyzes five central values: religiosity, nationalism, independence, cooperation, and integrity [11].

Strengthening character education can be interpreted as knowledge of the mental revolution movement and an integral part of Nawacita. The PPK movement places character education as the deepest or core dimension of national education so that character education becomes the implementation of primary and secondary education. Character education during the current COVID-19 pandemic is necessary for schools and at home, and in the social environment. Character education students are no longer early age adolescents, but adults.

A character is a form of human activity in which there is an educational action intended for the next generation. Character is one's disposition, disposition, or natural disposition. The purpose of character education is to shape individual self-improvement continuously and train oneself towards a better life. The family environment is the center of cultivating the character of an individual [12]. Children's character can be formed through a system of information on the behavior of parents in the family, forms of social relations with peers or other people, humanistic communication, and others, but the essential thing in children's character are the education of parents because the child's development is based in the family environment.

Based on the results of the questionnaire filled out in the google form application that has been disclosed to the child's parents, it is said that the urgency in providing an increase in the value of the character of responsibility to children is. First, make it a habit to admit and apologize when you make a mistake. Second, familiarize and assist children in learning, teaching, and learning, and doing their schoolwork. Third, give a warning to children who have not fulfilled their responsibilities towards their obligations at home. Fourth, it reminds us to behave well and politely towards others.

The roles built through this concept will be applied to informal learning during the COVID-19 pandemic. Also, parents will continue to nurture children's development in practice and character at home. For this reason, parents will be considered role models; all parental behavior will be accepted by children, what parents do; children think this is true. Therefore, parents must set a positive example for children in the family environment during the COVID-19 pandemic.

[13] Strengthening Character Education, among others, can be done through modeling, learning, empowerment, and culture as well as through strengthening. The results showed strengthening the character given through first, giving examples to each other, instilling positive habituation, mutual supervision, and appreciation. Second, directing and guiding children if they are not by existing norms, as parents can give advice or give warnings that build children's character so that they do not want to build the same thing in the future. 
Third, building a child's spiritual relationship with an almighty God means a spiritual relationship with God is built through the implementation and appreciation of ritual worship implemented in social life. Fourth, doing good things.

Exemplary and habitual moral education is a strategy for character building in children. Exemplary parents can provide examples of behavior to their children. Habit in the character education process is essential. Habitual is a very effective way of character education for children. The values in character education that have been embedded in him can be implemented in everyday life.

Responsibility is to emphasize positive obligations to care for one another [14].This can be seen from the child's ability to witness their duties. A child's task is to carry out his obligations that must be carried out daily, while the responsibility is the child's authority to fulfill these obligations [15]. In learning activities at home, the command of responsibility for children begins with the child's awareness that they must be responsible for everything, including homework, so they have to do it.

The participatory role of parents or families actively in supporting education is called their children. Permendikbud Number 30 of 2017 concerning the family's involvement in the implementation of education that the family is involved in the implementation of education fosters synergy in the education unit, family, and community. Education that has an organizational synergy can foster positive things related to character and learning outcomes. Ki Hajar Dewantara is committed that education is very much determined by the family, seeing the family in its foundation to be called the center of education.

In the COVID-19 pandemic, parents have a relatively large and confident role in developing character values at home. During the COVID-19 pandemic, the communication between parents and children is very much. They are giving responsibility for the child in the home the role of parents as a facilitator who helps children build compelling character. Parents can act as filters that help filter out various negative influences that are not good for their development, and parents can act as a liaison for children with learning resources close to their daily environment.

The positive actions taken at home will form an excellent emotional bond between the child and the parents. Relationships that will crash during activities together, foster love which later becomes a habit [16]. Actions like this are perfect for children in the family environment by implementing the positive strategies given during the COVID-19 pandemic with the hope that this will continue until when the COVID-19 pandemic ends, this pattern will continue.

\section{CONCLUSION}

The role of parents is as a guide, caregiver, guardian, mentor and mentor, and especially the role of parents is to protect and guarantee their children to lead a dignified life. Based on the results of research on strengthening character education provided by parents at the time of the COVID-19 pandemic in children, it can be collected through the following things. (1) Always teach discipline and responsibility with examples of homework that have been divided, starting from small things that can be practiced. (2) procedures for habituation, appreciation, and advice. (3) To be a good role model for children, they must obey the rules that apply at home, one of which is to go home before sunset and study after night. (4) entering a holiday will allow children to play with gadgets or play with friends. (5) equip children with religious knowledge because of the help of others.

A sense of responsibility will arise if parents and children understand their functions and duties at home, parents educate, children follow them. Good and moral education habituation is a strategy for character building in children. Exemplary parents can provide examples of behavior to their children. Habits in the character education process are essential, beneficial habits for character education for children. The values in character education that have been embedded in him can be implemented in everyday life. The responsibility given is about school assignments, but responsibility in the home environment is also significant because it will benefit social life. Parents must be role models for students in shaping and assisting students. It can be seen that homes became schools during the COVID-19 pandemic, so it can be seen that parents are the leading figures in education for students now.

\section{ACKNOWLEDGMENTS}

Thank you to the resource person in Telukmerbau village, Rokan Hilir, Riau. They are parents of children who received education in the area.

\section{REFERENCES}

[1] S. M. Towaf, "Pendidikan Karakter Pada Matapelajaran Ilmu Pengetahuan Sosial,” J. Ilmu Pendidik., vol. 20, no. 1, pp. 75-85, 2014 [Online]. Available: http://journal.um.ac.id/index.php/jip/article/view 14380.

[2] E. Widianto, "Peran Orang Tua Dalam Meningkatkan Pendidikan Karakter Anak Usia Dini Dalam Keluarga," PG-PAUD Trunojoyo, vol. 2, no. 1, pp. 31-39, 2015.

[3] P. A. Chusna, "Pengaruh Media Gadget Pada Perkembangan Karakter Anak," Din. Penelit. Media Komun. Sos. Keagamaan, vol. 17, no. 2, pp. 315-330, 2017, [Online]. Available: https://e-

resources.perpusnas.go.id:2093/doi/abs/10.1142 
/S0192415X20500500.

[4] 2017 Nurlaeni \& Juniarti, "PERAN ORANG TUA DALAM MENGEMBANGKAN KEMAMPUAN BAHASA PADA ANAK USIA 4-6 TAHUN PENDAHULUAN Pendidikan adalah proses pemberian rangsangan pendidikan dimulai dari sejak lahir sampai usia enam tahun untuk dan membantu pembelajaran yang dilaksanakan oleh indiv."

[5] S. Sukaimi, "Peran Orang Tua Dalampembentukan Kepribadian Anak: Tinjauan Psikologi Perkembangan Islam," Marwah J. Perempuan, Agama dan Jender, vol. 12, no. 1, p. 81, 2013, doi: 10.24014/marwah.v12i1.515.

[6] N. Cahyati and R. Kusumah, "The Role of Parents in Applying Learning at Home During the Covid Pandemic 19," J. Golden Age, Univ. Hamzanwadi, vol. 04, no. 1, pp. 4-6, 2020.

[7] W. L. Neuman, Metodologi penelitian sosial pendekatan kualitatif dan kuantitatif edisi 7. jakarta:indeks,2013.

[8] Sugiyono, Educational research methods. Bandung: Alfabeta, 2014.

[9] G. F. A. Ariyanti Novelia Candra*, Ari Sofia2*, "Gaya Pengasuhan Orang Tua pada Anak usia Dini," vol. 3, no. 2, 2017.

[10] S. Zahrok and N. W. Suarmini, "Peran Perempuan Dalam Keluarga," IPTEK J. Proc. Ser., vol. 0, no. 5, p. 61, 2018, doi: 10.12962/j23546026.y2018i5.4422.

[11] P. Y. Purandina and Made Astra Winaya, "Pendidikan Karakter di Lingkungan Keluarga Selama Pembelajaran Jarak Jauh pada Masa Pandemi COVID-19," Cetta J. Ilmu Pendidik., vol. 3, no. 2, pp. 270-290, 2020, doi: 10.37329/cetta.v3i2.454.

[12] K. Kristjansson, Aristotelian character education. Routledge: New York, 2015.

[13] S. Daryanto, and Darmiatun, Implementation of Character Education in Schools. Yogyakarta: Gava Media, 2013.

[14] N. M. Ratminingsih, Teaching, character, and love. Singaraja. Mahima Institute, Indonesia, 2019.

[15] T. Lickona, Educating For Character: How Our School Can teach respect and responsibility. Canada: Inc Bantams Books, 2013.

[14] K. Novitasari, "Tanggung Jawab Pada Anak Kelompok B Di Tk Nasima Kota,” pp. 1-9, 2018. 